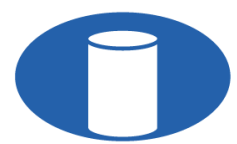

IBRACON

\title{
Thermal numerical analysis of steel and steel and concrete composite columns in a fire situation aimed at the evaluation of the simplified method of ABNT NBR 14323:2013
}

\author{
Análise numérica térmica de pilares de aço e mistos de aço e concreto em situação \\ de incêndio visando a avaliação do método simplificado da ABNT NBR 14323: 2013
}

Mariana Lavagnolli Rossi ${ }^{\mathrm{a}}$ (D)
Yagho de Souza Simões $^{\mathrm{a}}$ (D)
Jorge Munaiar Neto $^{\mathrm{a}}$ (D)
Alessandra Lorenzetti de Castro $^{\mathrm{a}}$

${ }^{\text {a }}$ Universidade de São Paulo - USP, Escola de Engenharia de São Carlos - EESC, Departamento de Estruturas, São Carlos, SP, Brasil

Received 12 November 2020 Accepted 23 February 2021

\begin{abstract}
The design of steel and steel and concrete composite columns in a fire situation is directly linked to the reduction of strength and stiffness, among other properties, which are manifested in response to rising temperatures. The normative codes that deal with the design of these elements under the action of fire consider the thermal action based on heating on the four faces of the column, an aspect that does not cover most cases in buildings due to the presence of walls. In this context, given the importance of the correct determination of the thermal field for design purposes, as well as given the simplification adopted by the normative codes, the present work deals exclusively with a study basically aimed at obtaining a representative thermal field for purposes of thermo-structural verification of steel and steel and concrete composite columns. With the focus on the analysis of cases that differ from the prescribed configurations in standards, purely thermal numerical models are proposed, validated through experimental results, whose analyses show an evident reduction in temperature in the steel column when encased with concrete, and with even greater evidence when additionally inserted into walls as a compartmentalizing element. To verify the simplified method proposed by ABNT NBR 14323: 2013, comparative analyses between the numerical thermal fields and obtained by the standardized model were carried out for steel and steel and concrete composite cross sections. For the isolated steel columns, as expected, the normative method proved to be consistent, but conservative when it came to columns inserted into walls. In relation to the composite columns, the results obtained indicate the need for adjustment in the standards for purposes of determining the thermal field and, consequently, of design these elements.
\end{abstract}

Keywords: steel and concrete composite columns partially encased, steel columns, walls, fire, fire resistance.

Resumo: O dimensionamento de pilares de aço e mistos de aço e concreto em situação de incêndio está diretamente atrelado à redução da resistência e da rigidez, entre outras propriedades, as quais se manifestam em resposta à elevação da temperatura. Os códigos normativos que tratam do dimensionamento desses elementos sob ação do fogo consideram a ação térmica com base em aquecimento nas quatro faces do pilar, aspecto que não abrange a grande maioria dos casos nas edificações em função da presença de paredes. Nesse mesmo contexto, dada a importância da correta determinação do campo térmico para fins de dimensionamento, bem como dada a simplificação adotada pelos códigos normativos, o presente trabalho se volta exclusivamente a um estudo basicamente direcionado à obtenção de campo térmico representativo para fins de verificação termoestrutural de pilares de aço e mistos. Tendo como foco principal a análise de casos que diferem das configurações prescritas em normas, são propostos modelos numéricos puramente térmicos validados por meio de resultados experimentais, cujas análises constatam uma evidente redução da temperatura no pilar de aço quando revestido com concreto, e ainda com maior evidência quando adicionalmente inseridos em paredes enquanto elemento de compartimentação. De modo a verificar o método simplificado proposto pela ABNT NBR 14323:2013, análises comparativas entre os campos térmicos

Corresponding author: Yagho de Souza Simões. E-mail: yaghosimoes@usp.br

Financial support: None.

Conflict of interest: Nothing to declare.

This is an Open Access article distributed under the terms of the Creative Commons Attribution License, which permits unrestricted use, distribution, and reproduction in any medium, provided the original work is properly cited. 
numérico e obtido pelo modelo normatizado foram realizadas para seções transversais de aço e mistas de aço e concreto. Para os pilares de aço isolados, como esperado, o método normativo se mostrou consistente, porém conservador quando voltado a pilares inseridos em paredes. Em relação aos pilares mistos, os resultados obtidos sinalizam a necessidade de ajuste nas prescrições normativas para fins de determinação de campo térmico e, consequentemente, para fins de dimensionamento desses mesmos elementos.

Palavras-chave: pilares mistos de aço e concreto parcialmente revestidos, pilares de aço, paredes, incêndio, resistência ao fogo.

How to cite: Rossi et al. "Thermal numerical analysis of steel and steel and concrete composite columns in a fire situation aimed at the evaluation of the simplified method of ABNT NBR 14323:2013", Rev. IBRACON Estrut. Mater., vol. 14, no. 5, e14502, 2021, https://doi.org/10.1590/S198341952021000500002 .

\section{INTRODUCTION}

Concrete and steel are widely used in civil construction. The perception of the efficient work developed individually by these materials allowed the appearance of composite elements of steel and concrete, which started to be used to bond the advantages brought by both materials.

Among the countless advantages of using steel and concrete composite structures, good fire resistance is worth mentioning. According to Correia and Rodrigues [1], concrete, due to its lower thermal conductivity and higher specific heat when compared to steel, increases the fire resistance of metallic elements, since it acts as a protective coating against thermal action, in addition to contributing structurally. Still in relation to this association, steel reduces the effects of cracking and spalling in concrete. According to Simões et al. [2], concrete increases the fire resistance of the purely steel element, because by reducing the average temperature of the set, it can present a resistant capacity for a longer time.

Currently, the rules that address the design of steel and composite columns partially encased in a fire situation are the Brazilian standard ABNT NBR 14323 [3] and Eurocode 3 and 4 Part 1-2 [4], [5], but they only include the scenario where the columns are subjected to heating on all faces of the cross section. However, in current structures most, or almost all, of the columns are inserted into walls, so that, in a fire situation, they present a different structural behavior than when isolated.

The presence of the wall in contact with the column generates a thermal gradient in its cross section since one side of the column is subject to thermal action, and the other is not, promoting the formation of curvature in the structural element and, consequently, additional bending moments from the phenomenon called Thermal Bowing [6].

Rocha [7] points out that, although there are scientific studies in the experimental and numerical spheres regarding columns subjected to thermal gradients, there are few studies regarding the influence of walls on the thermal behavior of these elements, as they seek to simulate the differential heating of the columns originated from masonry, through thermal protection of some faces of the columns, as performed in Dwaikat and Kodur [8], Dwaikat et al. [9], Agarwal et al. [10].

Most works deal with purely steel columns and, exceptionally, steel and concrete composite columns. In this context, some studies assess the influence of partially or fully encasing or filling steel columns with concrete under fire situations. The benefits of this material in both the fire resistance and structural behavior can be identified $[1,2,11]$. When associated with masonry walls, research is even more scarce, thus emphasizing the importance of the present study.

Considering the above, the present work seeks to study the influence of the filler concrete between the flanges and the masonry wall in determining the thermal field developed in the cross section of steel and steel and concrete composite columns partially encased inserted into walls, in situations of fire. Although the present text focuses only on the analysis of temperature levels, this analysis is of fundamental importance for the purposes of design since the thermal field is determinant in a thermo-structural context.

For this purpose, thermal numerical models developed with the aid of ABAQUS are proposed, whose numerical results are validated through experimental results presented in Rocha [7], allowing evaluations in relation to the temperature field and the thermal gradient presented by these elements under high temperatures. In a complementary way, but not less important, comparisons will also be made between the temperature evolution of steel and steel and concrete composite columns with that achieved when applying the simplified methods of ABNT NBR 14323 [3] and Eurocode 3 and 4 Part 1-2 [4], [5]. 


\section{EXPERIMENTAL REFERENCE ANALYSIS}

As previously mentioned, the present work is based on results of prototypes related to the experimental program presented in Rocha [7], whose characteristics are described in Table 1. For purposes of identifying the columns, the nomenclature used adopts the type of steel profile (HEA 220), the relative position of the web of the metal profile in relation to the walls (parallel or orthogonal), the thickness of the ceramic block used for the construction of the wall $(11 \mathrm{~cm}$ or $15 \mathrm{~cm})$ and the presence or absence of concrete coating (CONC). The columns that received the thermal action on the four faces also receive the term ISO for identification purposes.

Table 1. Characteristics of the columns used in the numerical modeling.

\begin{tabular}{cccccc}
\hline Number & Reference & HEA Profile & Web orientation & Block thickness & $\begin{array}{c}\text { Presence of } \\
\text { concrete }\end{array}$ \\
\hline 1 & H220-PAR-T15 & 220 & Parallel & $15 \mathrm{~cm}$ & - \\
\hline 2 & H220-ORT-T15 & 220 & Orthogonal & $15 \mathrm{~cm}$ & - \\
\hline 3 & H220-CONC-PAR-T15 & 220 & Parallel & $15 \mathrm{~cm}$ & Yes \\
\hline 4 & H220-CONC-ORT-T15 & 220 & Orthogonal & $15 \mathrm{~cm}$ & Yes \\
\hline 5 & H220-CONC-PAR-T11 & 220 & Parallel & $11 \mathrm{~cm}$ & Yes \\
\hline 6 & H220-CONC-ORT-T11 & 220 & Parallel & $11 \mathrm{~cm}$ & - \\
\hline 7 & H220-ISO & 220 & - & - & Yes \\
\hline 8 & H220-CONC-ISO & 220 & - & Yes \\
\hline
\end{tabular}

The steel and steel and concrete composite columns, both with HEA 220 profile, had a length of $2940 \mathrm{~mm}$. In relation to the composite columns, the concrete inserted between the profile flanges had a characteristic resistance to compression equal to $30 \mathrm{MPa}$, which was reinforced longitudinally with bars with a diameter equal to $20 \mathrm{~mm}$, as well as transversely with stirrups with a diameter equal to $8 \mathrm{~mm}$ spaced every $150 \mathrm{~mm}$. All reinforcements had a yield strength equal to $500 \mathrm{MPa}$. The dimensions of the cross section can be seen in Figure 1. In the experiments, the walls were made using ceramic blocks and mounted separately from the columns, presenting the same length in relation to the columns and arranged $1200 \mathrm{~mm}$ on each side.

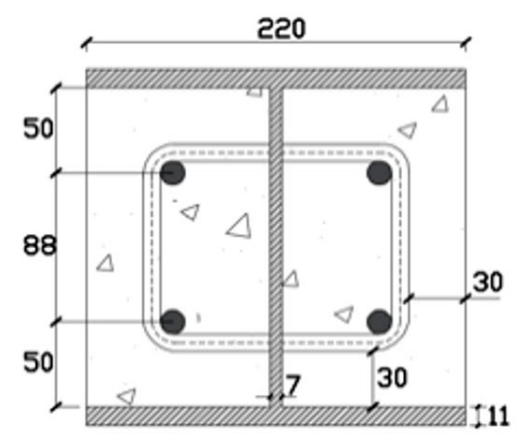

(a)

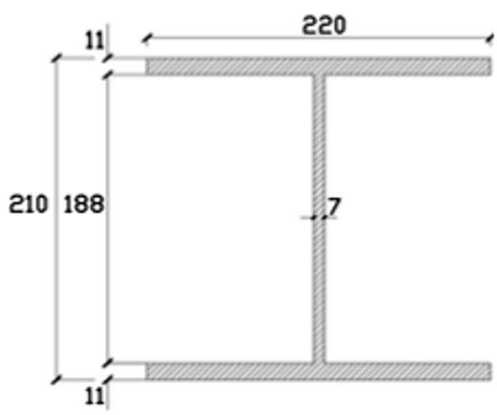

(b)

Figure 1. Geometric characteristics of the studied columns, considering as cases of interest: (a) steel and concrete composite, and (b) Purely steel.

The columns were inserted in a three-dimensional constraint structure in order to simulate the columns inserted in a real structure. The structural elements were heated using a modular electric oven made up of three modules, two of which are $1.0 \mathrm{~m}$ high and the other $0.5 \mathrm{~m}$ and for that reason, only $2.5 \mathrm{~m}$ of the central part of the columns were heated.

The presentation of the results and the validation of the proposed models were made with reference to the section (central), as it has the highest temperature among the others and also did not suffer the influence of the less heated extremities. Thus, this region presents the greatest degradation of its mechanical properties, which negatively affects the thermo-structural behavior of the columns. 


\section{NUMERICAL ANALYSIS CARRIED OUT IN THERMAL CONTEXT}

\subsection{General aspects regarding the numerical strategy adopted}

The proposed numerical models sought to evaluate the influence of the filler concrete and walls on the thermal field generated in steel and steel and concrete composite columns in a fire situation. According to Rocha [7], the experimental analysis of columns attached to the walls has many peculiarities that hinder the numerical modeling of this set, which is why the strategies adopted are described below.

The numerical modeling was performed with the ABAQUS code 6.18 version, which is based on the Finite Element Method. To represent the steel profiles finite shell elements (DS4) were used, the filler concrete and masonry walls were reproduced with solid elements (C3D8), while the steel reinforcements present in the concrete were modeled with bar elements (T3D2). The identification of the finite element by ABAQUS for each structural component is shown in Table 2, in which quadratic finite elements with a size of $30 \mathrm{~mm}$ were adopted.

The walls were reproduced by means of a "macro-modeling" and represented as a massive block with dimensions representative of the experimental model, that is, $50 \mathrm{~cm}$ for each side of the column (corresponding to the region heated by the oven), and with block thickness varying between 11 and $15 \mathrm{~cm}$. According to Lourenço [12], this strategy presents good efficiency and still allows to consider the masonry blocks and mortar joints as a unique element of homogeneous properties.

Figure 2 shows the cross section of the columns H220-CONC-ORT-T11 and H220-CONC-PAR-T11. The other models were built in a similar way, changing only the dimensions of the cross section, the thickness of the compartmentalization elements and the presence or not of masonry and concrete.

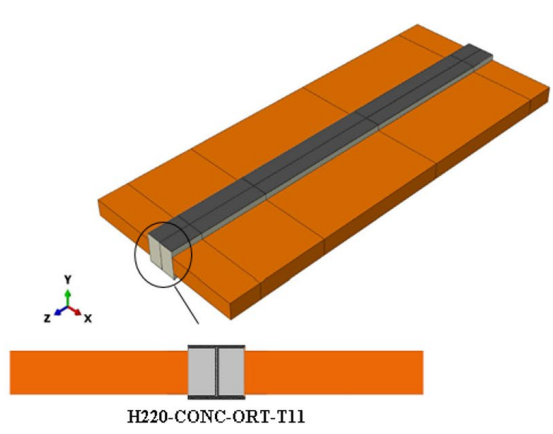

(a)

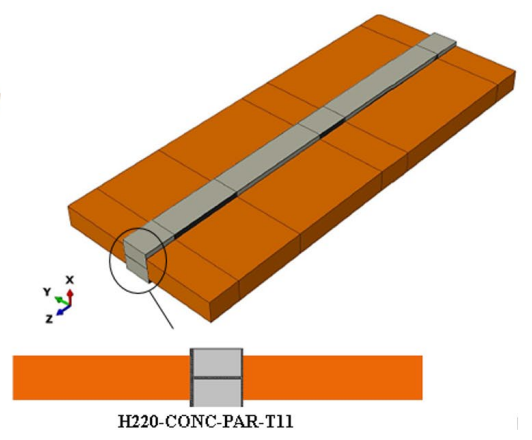

(b)

Figure 2. Representation of the thermal models for the columns: a) H220-CONC-ORT-T11; b) H220-CONC-PAR-T15.

\subsection{Boundary conditions and material properties}

The columns were modeled with the heating curves of the gases obtained in the experimental tests, emphasizing that these curves were not coincident with the standard fire curve defined by ISO 834-1 [13]. Regarding the boundary conditions of a thermal modeling, the three phenomena of heat exchange (convection, radiation and conduction) between the environment and the element were used, along with their respective coefficients and the active regions.

Regarding the modeling of columns inserted into walls, the exposed and non-exposed sides were considered in the construction of the thermal model. Concerning the exposed face, the Brazilian standard ABNT NBR 14323 [3] considers the convection coefficient equal to $25 \mathrm{~W} / \mathrm{m}^{2 \circ} \mathrm{C}$ and the emissivity of 0.7 for the steel and concrete surfaces, while for the non-exposed side to fire it does not make reference to which values to adopt. Eurocode 1 Part 1-2 [14], in turn, allows two options to be considered: one can consider the effects of convection and radiation together by means of a convection coefficient equivalent to $9 \mathrm{~W} / \mathrm{m}^{2}{ }^{\circ} \mathrm{C}$, or admit these phenomena separately, so that the convection coefficient is equal to $4 \mathrm{~W} / \mathrm{m}^{2 \circ} \mathrm{C}$ with the emissivity value dependent on the material used.

With regards to the thermal properties used for the materials under analysis, for steel and concrete, those described by ABNT NBR 14323 [3] were used, while for the walls, information was used according to Cadorin [15], which are: $840 \mathrm{~J} / \mathrm{kg}^{\circ} \mathrm{C}$ for specific heat and $1600 \mathrm{~kg} / \mathrm{m}^{3}$ for specific mass. 


\subsection{Validation of the numerical model in thermal context}

During the processing of the numerical thermal models for the purposes of calibration and validation, it is worth mentioning that the results obtained were not satisfactory using normative concepts as emissivity. Therefore, based on Simões et al. [2], [16], sensitivity analyses for emissivity were developed to obtain more representative values for the same parameter. Table 2 presents the parameters that best represented the experiments in Rocha [7]. The value adopted for the emissivity of steel on the exposed side was 0.8 , differing from that recommended by the European normative code, which is 0.7 . Nevertheless, this change can be accepted, since the scenario of the gas oven used in the experimental tests is different from an actual fire. Since the European normative codes do not specify values for unexposed surfaces, it was adopted those values that best described the thermal numerical model, which were 0.6 for steel surfaces and 0.7 for concrete and wall surfaces.

Table 2. Parameters adopted for calibration of the thermal numerical model.

\begin{tabular}{cccccc}
\hline & \multicolumn{2}{c}{ Exposed side } & & \multicolumn{2}{c}{ Non-exposed side } \\
\cline { 1 - 2 } Surface & Emissivity & $\begin{array}{c}\text { Convection } \\
\text { Coefficient } \mathbf{~} \cdot \mathbf{m}^{2} /{ }^{\circ} \mathbf{C}\end{array}$ & & Emissivity & $\begin{array}{c}\text { Convection Coefficient } \\
\mathbf{W} \cdot \mathbf{m}^{2} /{ }^{\circ} \mathbf{C}\end{array}$ \\
\hline Steel & 0.8 & 25 & 0.6 & 4 \\
\hline Concrete & 0.7 & 25 & 0.7 & 4 \\
\hline Wall & 0.7 & 25 & 0.7 & 4 \\
\hline
\end{tabular}

Figure 3 shows the validation of the proposed thermal modeling for some of the analysed columns, from the comparison between numerical and experimental temperature evolution curves in the section located at half height of the column, according to Rocha [7]. In the same figure, it is possible to visualize the positions of the thermocouples in each of the studied columns, whose nomenclature used for the reading points was established as TX, where X represents the reading point of the central section of the column.

In general, it is noted that the maximum temperature difference found, between numerical and experimental results, resulted in around $50^{\circ} \mathrm{C}$ for the columns presented. Based on the curves presented in Figure 3, and highlighting that for the other mentioned column the same similarity was observed, it is possible to consider the numerical strategy adopted here as consistent, making it possible to use it for additional and specific analyses in a purely thermal context for the columns under analysis.

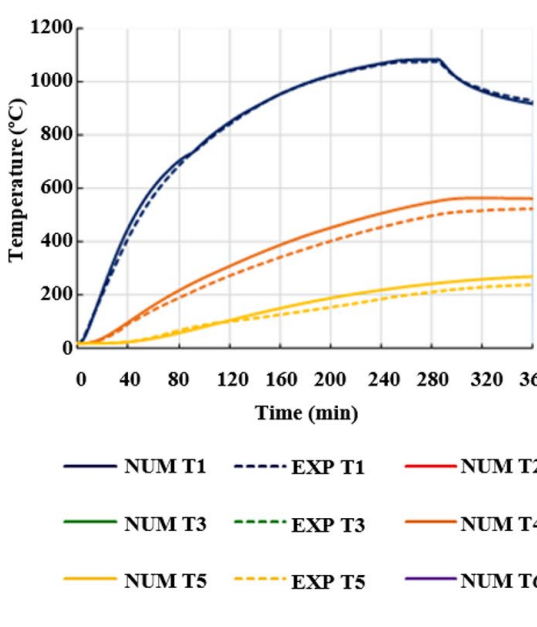

NUM: Numerical Result

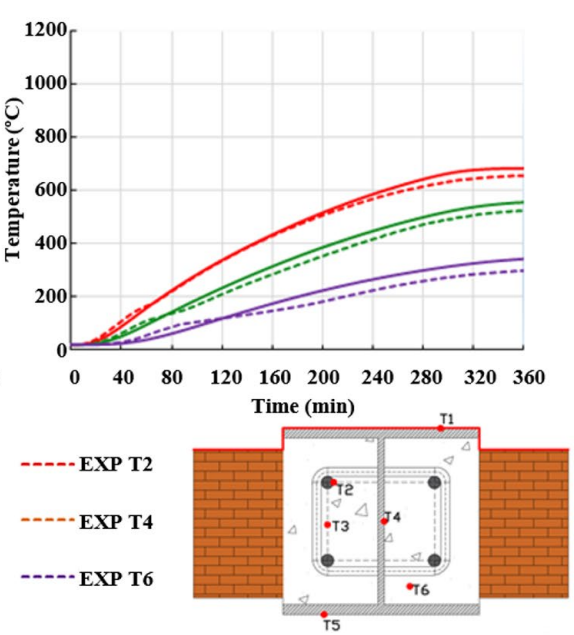

EXP: Experimental Result

Figure 3. Comparison of numerical models and experimental results: H220-CONC-ORT-T11. 


\section{INFLUENCE OF THE FILLER CONCRETE AND MASONRY WALL IN THE THERMAL FIELD OF COLUMNS}

Based on the proposed numerical strategy, according to item 3.3, as well as considering its consistency as results, studies will be carried out focused on the concrete and wall influences on the thermal behavior of the columns. As the idea is also to verify results obtained through the concepts of ABNT NBR 14323 [3], unlike the temperature curves adopted for the purpose of consistency analysis, as per item 3.1, the columns were modeled using the standard fire curve defined by ISO 834-1 [13], and with the thermal parameters recommended by the mentioned Brazilian standard, when available.

The studies presented in the items that follow aim to evaluate the influence of masonry walls and the filler concrete in the temperature field developed in the steel profile, which is why points located in predefined locations of the cross section will be studied in all the columns to carry out comparative analyses. Figure 4 shows the indication of the thermocouples considered in the columns analyzed here, remembering that the position of these in the columns H220- CONC-ORT-T11 and H220-CONC-PAR-T11 is identical to that of the columns H220-CONC-ORT-T15 and H220 -CONC-PAR-T15, respectively.

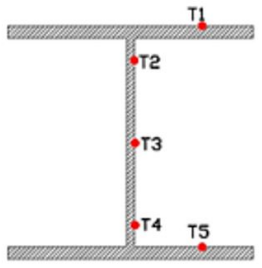

a) H220-ISO

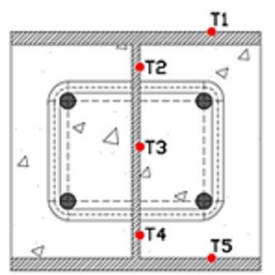

d) H220-CONC-ISO

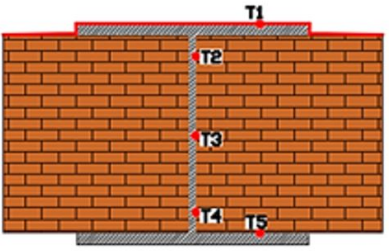

b) H220-ORT-T15

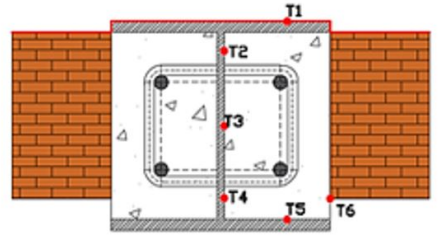

e) H220-CONC-ORT-T15

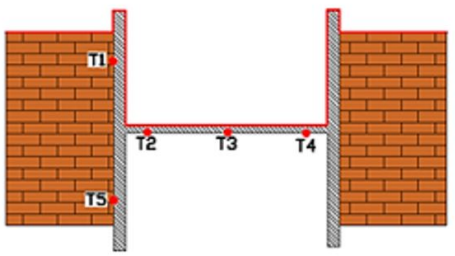

c) H220-PAR-T15

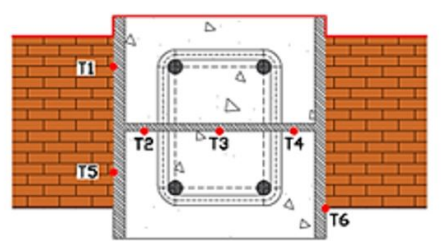

f) H220-CONC-PAR-T15

Figure 4. Positioning of thermocouples in the cross section of the columns under study.

\subsection{Evaluation of the influence of the filler concrete}

As a starting point, the influence of filler concrete on steel profiles subject to fire is analyzed. Figure 5 shows the representation of the thermal numerical models H220-ISO and H220-CONC-ISO, based on their symmetry, which present the temperature field developed in the cross section of the structural element for the instant equal to 120 minutes.

It is observed, through Figure 5, a difference in behavior between the two types of structural design. Immediately, it is possible to notice that, although the metal profile flange is exposed to fire in both situations, in the case of the steel and concrete composite column the temperature field becomes milder as it advances with depth, as expected.

Additionally, Figure 6 shows the evolution of temperatures for the steel and steel and concrete composite columns isolated during 120 minutes, in which a temperature reduction of $200^{\circ} \mathrm{C}$ is identified on the flange exposed to fire (T1/T5 thermocouple) in 30 minutes of exposure of the composite column, even though both flanges were in contact with the thermal action. With an increase in the duration of the thermal action, the same difference decreased due to the heat transfer phenomena. 


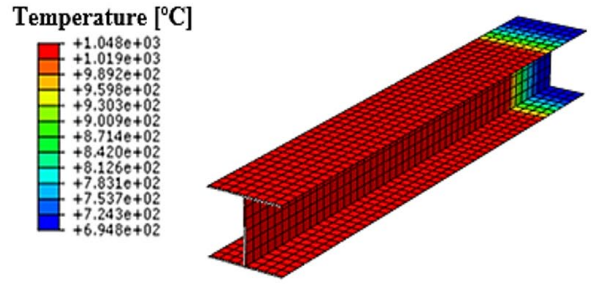

a)

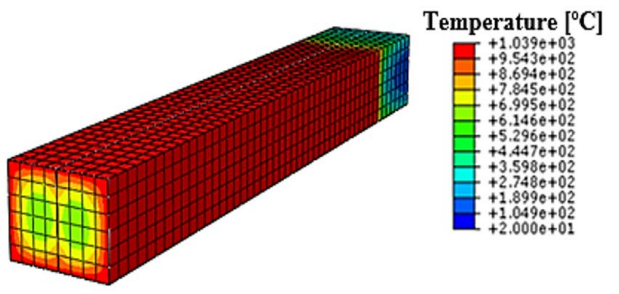

b)

Figure 5. Thermal field for the columns: (a) H220-ISO e (b) H220-CONC-ISO.

Regarding the web of the steel profile, at both points evaluated the temperature difference is even greater, around $400^{\circ} \mathrm{C}$ and $600^{\circ} \mathrm{C}$ at 30 minutes when comparing the temperatures in the T2 and T3 thermocouples, respectively. This aspect can be justified because the concrete works efficiently as a thermal insulator due to its thermal properties, such as low thermal conductivity, high specific heat, as well as forming more robust elements that hinder the propagation of heat.
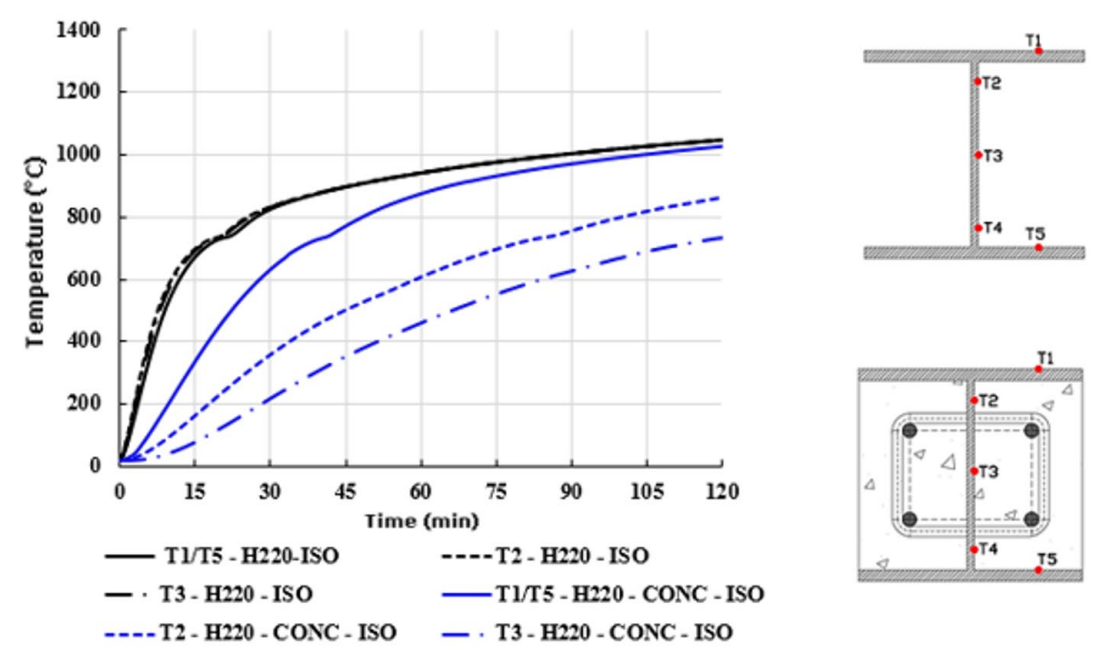

Figure 6. "Temperature vs time" curve for steel and composite H220-ISO columns.

\subsection{Evaluation of the influence of masonry walls}

Subsequently to the analysis of the influence of the filler concrete, the influence of the masonry walls on the thermal field of the purely steel columns was carried out. Figure 7 shows the temperature field formed in the cross section of the columns H220-ORT-T15 and H220-PAR-T15. In a general view, it is possible to verify the difference of the thermal field presented in the steel profile, because while the H220-ORT-T15 column presents a gradient along the web, in the H220-PAR-T15 column, this differential heating occurs around the flange. 

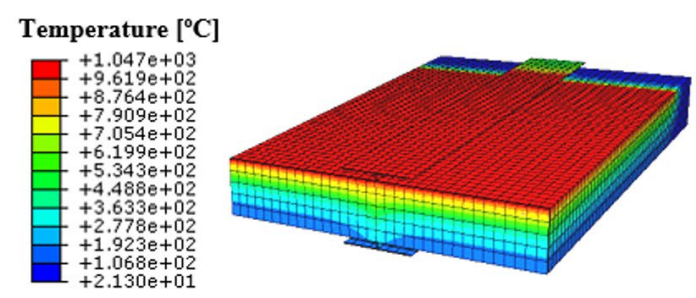

a)

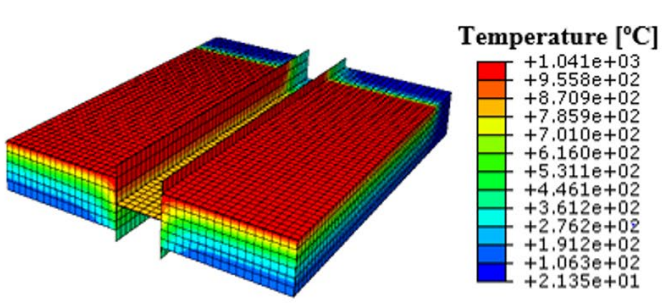

b)

Figure 7. Columns thermal field: (a) H220-ORT-T15; (b) H220-PAR-T15.

Figures 8 and 9 show the temperature distribution at points arranged on the web and on the flange, respectively, for the H220-ISO isolated steel columns and H220-ORT-T15 and H220-PAR-T15 columns inserted into walls. Similarly to what was identified as the influence of the filler concrete, as expected as well, there is a reduction in temperature in the steel profile with walls compared to the isolated column, since their presence, as partitioning, prevents the incident heat directly in the metallic profile, resulting in less heating and less marked reduction of its mechanical properties.

The insertion of the wall, according to the H220-ORT-T15 column, reduced the temperature of the steel profile flange (T5 thermocouple) by approximately $800{ }^{\circ} \mathrm{C}$ compared to the same profile without any thermal barrier at 60 minutes of exposure. Regarding the web, points T2 and T4, regions more and less heated, showed reductions close to $300^{\circ} \mathrm{C}$ and $700^{\circ} \mathrm{C}$, respectively, for the same time periods.

With respect to the H220-PAR-T15 column, the web (T2/T3/T4 thermocouples) showed a reduction of $200{ }^{\circ} \mathrm{C}$ at 120 min compared to the isolated steel column. The flange, for that same time, reduced its temperatures at points $\mathrm{T} 1$ and T5 (more and less heated regions, respectively) by values close to $100{ }^{\circ} \mathrm{C}$ and $500{ }^{\circ} \mathrm{C}$. This decrease was inferior to the previous case, the H220-ORT-T15 column, since one of the faces of the web and part of the flanges, in this type of structural design, is directly in contact with the flames, which makes its heating faster.

For the H220-ORT-T15 column, the formation of a thermal gradient along the web is observed. The region most exposed to fire (Thermocouple T1) is at a temperature close to $1050{ }^{\circ} \mathrm{C}$, while the T5 thermocouple, which is farthest from the thermal action, is close to $170{ }^{\circ} \mathrm{C}$ in $120 \mathrm{~min}$, allowing the identification of a thermal gradient close to $880^{\circ} \mathrm{C}$. Regarding the H220-PAR-T15 column, while heating, it is possible to notice that the web heats up evenly, while the flange has a thermal gradient depending on the position of the walls in that region. The temperature difference between the most heated points (thermocouple T1) and the least heated points (thermocouple T5) results in around $463^{\circ} \mathrm{C}$ at 120 minutes. Therefore, this column presents a more uniform heating compared to the H220-ORT-T15 column, suggesting a thermo-structural behavior similar to that of the isolated columns.
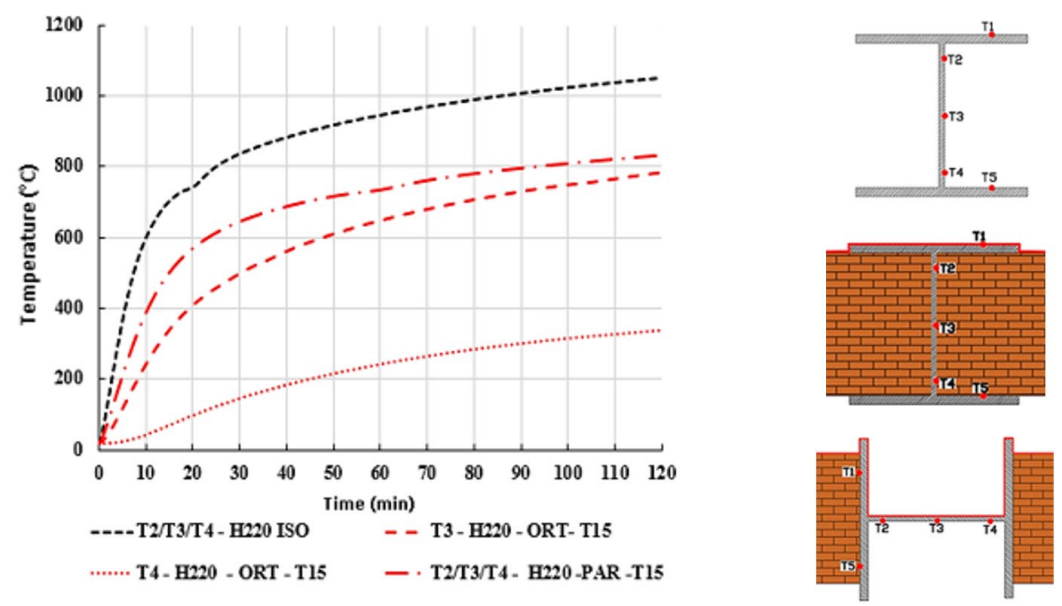

Figure 8. Curve referring to temperature as a function of time for isolated steel columns and steel columns inserted into walls, in contact with the flanges or with the web. 

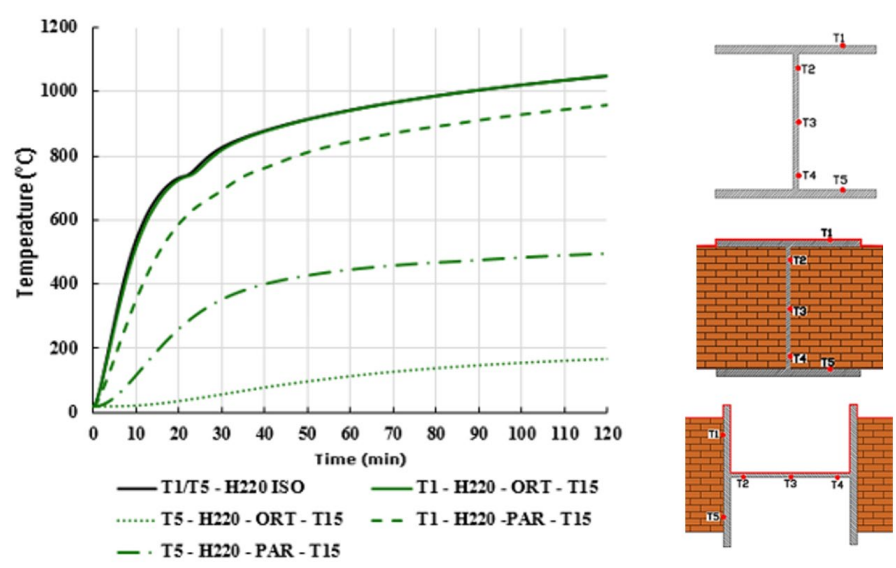

Figure 9. Curve referring to temperature as a function of time for isolated steel columns and steel columns inserted into the wall, in contact with the flanges or with the web.

After the separate analyses of the filler concrete and masonry walls, what follows is an analysis aimed at studying the simultaneous influence of concrete and wall on steel columns. First, the thermal field of the steel and concrete composite columns, H220-CONC-ORT-T15 and H220-CONC-PAR-T15, can be visualized, through Figure 10.

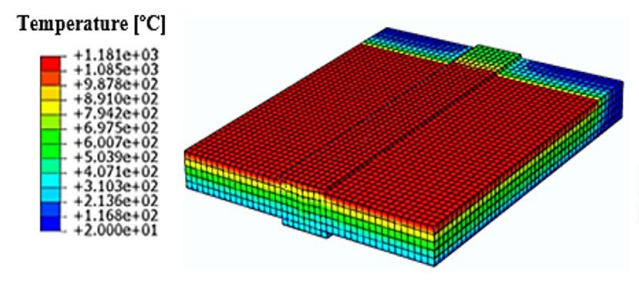

a)

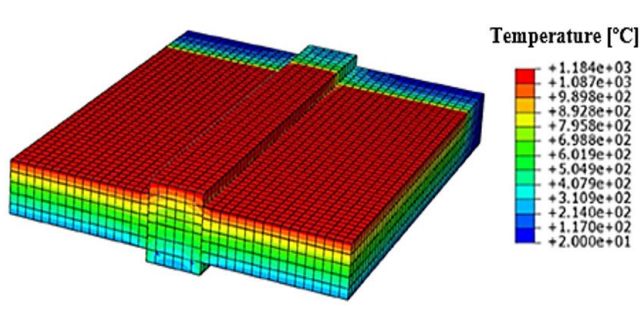

b)

Figure 10. Columns thermal field: a) H220-CONC-ORT-T15 e b) H220-CONC-PAR-T15.

In general, the differential heating mode presented by these columns is similar to the models shown in Figure 7. The H220-CONC-ORT-T15 column has a thermal gradient along the web, while on the H220-CONC-PAR-T15 column the differential heating takes place around the flange with a different intensity as generated temperature field. The temperature differences for these elements, during the 120-minute warm-up, occur according to Figures 11 and 12.

In all cases, the temperatures of the composite columns inserted into walls are lower when compared to the steel columns analyzed previously, since in these elements there are two materials acting as a thermal barrier, in this case, the concrete and the masonry walls. In the case of composite columns, the concrete acts as a thermal insulator of the steel profile, preventing the direct flow of heat in the element. In the purely metallic column, the thermal barrier consists of the masonry wall itself, which is in direct contact with the web or flange of the metallic profile, which consequently provides heat diffusion difficulty.

In this sense, in relation to the columns with the web orthogonal to the surface of the wall, in the region of the most heated flange (T1), the temperature difference between the composite and steel columns at 30 min was approximately $150^{\circ} \mathrm{C}$, reducing to about $50^{\circ} \mathrm{C}$ at 120 minutes. This small difference is justified by the fact that the thermal action acts directly on the steel profile flange, which facilitates the transmission of heat by the element. 

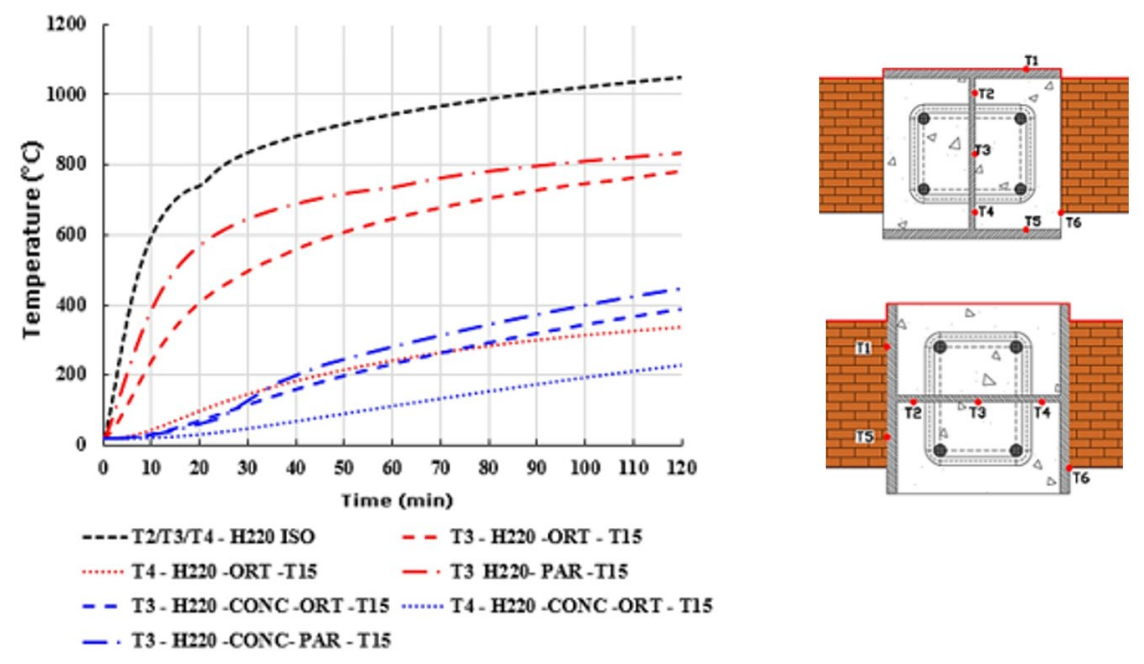

Figure 11. Curve for temperature versus time for columns (WEB).
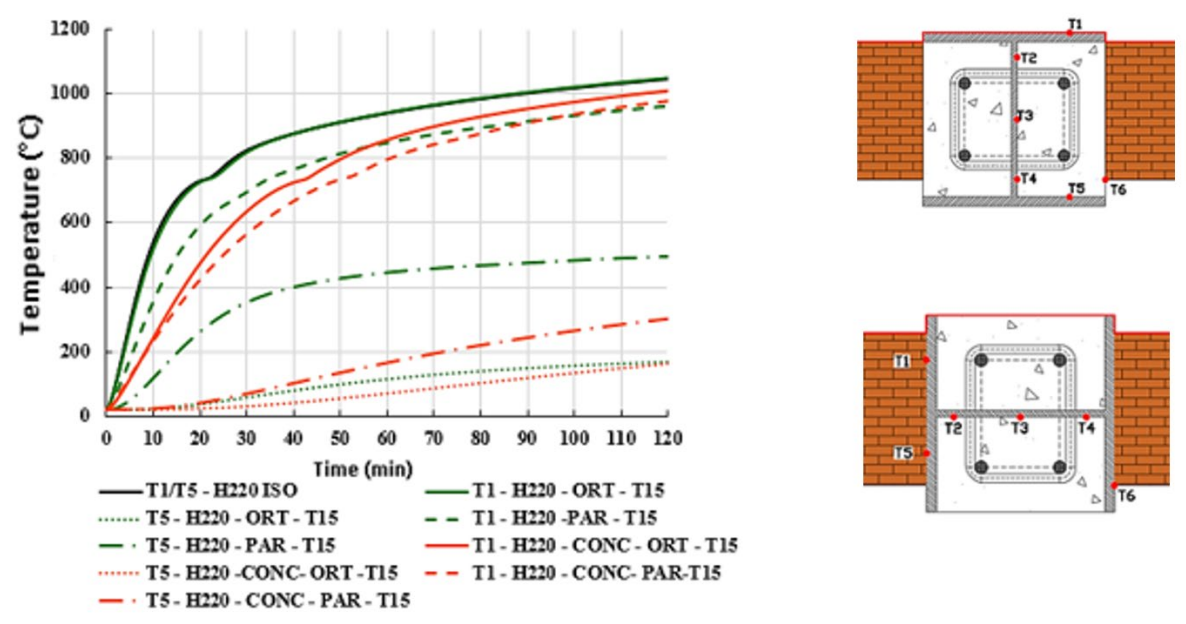

Figure 12. Curve for temperature versus time for columns (FLANGE).

In the case of columns with a web parallel to the wall surface, the thermal action against the steel profile is completely changed in the composite columns, because the web and part of the steel profile flange directly receive the heat from the flames. Thus, according to Figures 11 and 12, the temperatures of the most heated (thermocouple T1) and least heated (thermocouple T5) regions, referring to the flange, showed temperature reductions of about $150^{\circ} \mathrm{C}$ and $300^{\circ} \mathrm{C}$, respectively, compared to the steel columns inserted into walls at 30 minutes of exposure. Regarding heating the web for these columns (T3), there was a reduction of approximately $500^{\circ} \mathrm{C}$ in the first 30 minutes of exposure.

Regarding the H220-CONC-ORT-T15 column, which has a thermal gradient along the web, it is noted that the region most exposed to fire (Thermocouple $\mathrm{T} 1$ ) has a temperature equal to $1010^{\circ} \mathrm{C}$, while the $\mathrm{T} 5$ thermocouple, further from the thermal action, has $162^{\circ} \mathrm{C}$ in $120 \mathrm{~min}$ of exposure. In this sense, it was possible to observe a thermal gradient equal to $848{ }^{\circ} \mathrm{C}$, a value close to that found for the H220-ORT-T15 column. This similarity of results is due to the configuration of the structural elements. In both cases, the heat acts directly on one of the steel profile flanges and the web is protected, either by concrete or by the wall.

Regarding the H220-CONC-PAR-T15 column, the thermal gradient developed along the flanges, with a temperature difference between the most heated (T1) and least heated (T5) points around $677^{\circ} \mathrm{C}$ at 120 minutes, whose value it is more expressive when compared to that found for the H220-PAR-T15 column, since the composite column has the presence of concrete between the flanges, which ends up protecting the components of the steel profile, hindering the propagation of heat and increasing, consequently, the thermal gradient. 


\section{EVALUATION OF NORMATIVE MODELS TO OBTAIN TEMPERATURE IN STEEL AND COMPOSITE PROFILES}

This item evaluates the simplified method recommended by Brazilian standards ABNT NBR 14323 [3] and European Eurocode 3 and 4 Part 1-2 [4], [5] for calculating temperature in steel and concrete composite profiles partially encased when subjected to the action of fire. The purpose of this analysis is to compare the results of the thermal numerical models proposed here with those obtained through the application of normative theoretical methods. Such comparison has representativeness since the thermal numerical models were validated based on experimental results.

The normative method for determining the temperature in purely steel profiles, whether isolated or inserted into walls, was evaluated. As a result, it was concluded that it was satisfactory for columns with heating on all four sides, considering that the numerical and normative temperatures were close. In the case of columns inserted into walls, as expected, the standard proved to be quite in favor of safety, with differences between the average and normative numerical temperatures above $600^{\circ} \mathrm{C}$.

As the focus of this work is on the steel and concrete composite columns, the application of the simplified method for this structural design is described in detail below. For the case of steel and concrete composite columns partially encased in a fire situation, ABNT NBR 14323 [3] and Eurocode 4 Part 1-2 [5] present a specific method to determine their fire resistance. First, the temperature of each component of the cross section is found as a function of the required time of fire resistance (TRRF) and then used for the calculation of the normal resistant force.

The mentioned normative codes establish criteria for the application of this calculation procedure, which are related to the cross section of the composite elements (height, width and longitudinal reinforcement rate). They are presented in item B.3.2.1 of ABNT NBR 14323 [3] and are described below:

a) height of the cross section between $230 \mathrm{~mm}$ and $1100 \mathrm{~mm}$, with a minimum of $300 \mathrm{~mm}$ in the case of TRRF equal

to or greater than $90 \mathrm{~min}$;

b) cross-section width between $230 \mathrm{~mm}$ and $500 \mathrm{~mm}$, with a minimum of $300 \mathrm{~mm}$ in the case of TRRF equal to or greater than $90 \mathrm{~min}$;

c) rate of steel longitudinal reinforcement in relation to the concrete area from $1 \%$ to $6 \%$.

As illustrated in Figure 1a, the dimensions of the cross section of the composite columns of this study showed values very close to the intervals established by the method guidelines, with differences in height and width between $4 \%$ and $8 \%$, respectively. Considering the small difference found, by hypothesis it was considered reasonable to apply the normative calculation procedure described in Annex B of ABNT NBR 14323 [3] to obtain the temperature of the columns in a fire situation.

The mentioned standard divides the cross section of the columns into four components, namely: steel profile flanges, steel profile web, concrete between the flanges and longitudinal reinforcement. In this sense, each component must be evaluated based on its mechanical properties in a fire situation according to the TRRF.

The following also shows the average, maximum and minimum numerical temperatures for the four regions of the composite columns isolated and inserted into walls for TRRF equal to 30, 60, 90 and 120 minutes. These values are compared with those determined by the theoretical method proposed by the current standard. It is important to highlight that the normative codes do not include a calculation methodology to determine the temperature evolution in composite columns inserted into walls, that is, they are limited to composite columns with thermal action on their four faces (uniform heating). Despite this, the method was evaluated for all situations.

\subsection{Analysis of the temperature of the steel profile flanges}

ABNT NBR 14323 [3], in its item B.3.2.2.1, presents Equation 1 to determine the average temperature in the steel profile flanges, given in function of the section mass factor (ratio between the perimeter exposed to the fire, $\mathrm{u}$, and the gross cross-sectional area of the profile $\left.\left(A_{g}\right)\right)$, initial temperature $\left(\theta_{0, t}\right)$ and empirical coefficient $\left(k_{t}\right)$, the last two being obtained through the same standard as a function of TRRF values.

$\theta_{f, t}=\theta_{0, t}+k_{t}\left(u / A_{g}\right)$

Table 3 presents the temperature values obtained by the numerical and normative models for the steel and concrete composite column with heating on all sides, which is named H220-CONC-ISO. The results point to a good agreement 
between the presented values, with maximum difference between the numerical models and normative method of approximately $10 \%$.

Table 3. Comparison of theoretical temperatures and numerical model on steel profile flanges for composite columns with uniform heating.

\begin{tabular}{ccccc}
\hline TRRF (min) & $\mathbf{3 0}$ & $\mathbf{6 0}$ & $\mathbf{9 0}$ & $\mathbf{1 2 0}$ \\
\hline Normative & 730 & 858 & 919 & 987 \\
\hline H220-CONC-ISO & 657 & 880 & 973 & 1027 \\
\hline
\end{tabular}

Regarding the composite columns inserted into walls, Table 4 shows the average, maximum and minimum temperatures obtained in the numerical models. We chose to present these three possibilities in view of the thermal gradient that appears in the cross section due to the differential heating of the column.

It is possible to verify the low similarity of the average numerical values of the temperature in relation to the normative ones. In some cases, there was a difference in the thermal field above $400^{\circ} \mathrm{C}$ at 120 minutes of heating, indicating a certain conservatism of the referred standard. In contrast, the maximum temperature values of the numerical model were the ones that best approximated the temperature values obtained by the proposed normative method.

Table 4. Temperatures obtained in the numerical model on the steel profile flanges for the composite columns inserted into walls.

\begin{tabular}{|c|c|c|c|c|c|}
\hline Columns & TRRF (min) & 30 & 60 & 90 & 120 \\
\hline Normative & & 730 & 858 & 919 & 987 \\
\hline \multirow{3}{*}{ H220-CONC-ORT-T11 } & Average & 331 & 461 & 527 & 576 \\
\hline & Maximum & 637 & 864 & 957 & 1012 \\
\hline & Minimum & 26 & 57 & 98 & 139 \\
\hline \multirow{3}{*}{ H220-CONC-ORT-T15 } & Average & 332 & 463 & 536 & 586 \\
\hline & Maximum & 634 & 857 & 954 & 1010 \\
\hline & Minimum & 30 & 69 & 118 & 162 \\
\hline \multirow{3}{*}{ H220-CONC-PAR-T11 } & Average & 197 & 354 & 462 & 541 \\
\hline & Maximum & 631 & 847 & 949 & 1008 \\
\hline & Minimum & 93 & 205 & 284 & 337 \\
\hline \multirow{3}{*}{ H220-CONC-PAR-T15 } & Average & 186 & 337 & 442 & 524 \\
\hline & Maximum & 568 & 798 & 912 & 979 \\
\hline & Minimum & 76 & 166 & 244 & 302 \\
\hline
\end{tabular}

\subsection{Analysis of the temperature of the steel profile web}

For the web of the steel profile, ABNT 14323 [3] does not refer to the calculation methodology to determine its temperature. However, in order to dimension the normal plastification force in a fire situation, item B.3.2.3.2 presents Equation 2 for calculating the yield resistance of this region, which is a function of the steel yield resistance at room temperature $\left(f_{y}\right)$, the height of the composite section $\left(d_{c}\right)$ and the $H_{t}$ value that is obtained by the Brazilian standard for each TRRF.

$f_{y, \theta, w}=f_{y} \sqrt{1-\left(0.16\left(\frac{H_{t}}{d_{c}}\right)\right.}$

From Equation 2, by hypothesis, a reduction factor was determined for the yield resistance of rolled steel ( $\left.f_{y, \theta, w}\right)$, which corresponds to the portion that multiplies the steel yield resistance at room temperature $\left(f_{y}\right)$. Thus, an analogy was made with values provided by Table 1 of item 5.1.1.2 of ABNT NBR 14323 [3], which corresponds to a reduction coefficient for the mechanical properties of steel.

Due to the presence of concrete, the column with heating on all sides presents a thermal gradient along the web. Therefore, Table 5 shows the average, maximum and minimum temperature values in the numerical model and the theoretical values obtained when applying the normative concepts. 
From this table, it is possible to verify that the numerical average values for the web temperature of the steel profile are reasonably represented by the normative values, although with differences close to $20 \%$. In relation to the maximum temperatures, the normative values showed great differences in comparison to the numerical model, whereas for the minimum numerical temperatures, the norm was consistent.

Table 5 - Comparison of the temperatures obtained in the numerical model with the normative values for the steel profile web for the isolated composite column.

\begin{tabular}{cccccc}
\hline & TRRF (min) & $\mathbf{3 0}$ & $\mathbf{6 0}$ & $\mathbf{9 0}$ & $\mathbf{1 2 0}$ \\
\hline Normative & & 465 & 544 & 622 & 710 \\
\hline \multirow{3}{*}{ H220-CONC-ISO } & Average & 370 & 612 & 760 & 864 \\
\cline { 2 - 6 } & Maximum & 576 & 815 & 932 & 998 \\
\cline { 2 - 6 } & Minimum & 228 & 466 & 632 & 736 \\
\hline
\end{tabular}

In the case of columns inserted into walls, for comparison purposes, the average, maximum and minimum temperatures were also analyzed in the numerical models for columns with the web orthogonal to the wall. As for columns with a parallel web, this variation was not considered, since the web of the steel profile has practically no thermal gradient during the heating process.

As can be seen in Table 6, the average numerical temperatures of the web, regardless of the orientation of the steel profile in front of the wall, showed significant differences in relation to the theoretical values, with differences greater than $300^{\circ} \mathrm{C}$ at 120 minutes of heating. Regarding the maximum and minimum values, there was practically no agreement with the normative values. It is worth mentioning that, as well as obtained for the steel profile flange, the conservatism of the standard for determining the temperature in the profile web was observed when considering the average temperature of the composite column.

Table 6. Comparison of the temperatures obtained in the numerical model with the normative values for the steel profile web of the composite columns inserted into walls.

\begin{tabular}{cccccc}
\hline Columns & TRF (min) & $\mathbf{3 0}$ & $\mathbf{6 0}$ & $\mathbf{9 0}$ & $\mathbf{1 2 0}$ \\
\hline Normative & & 465 & 544 & 622 & 710 \\
\hline \multirow{3}{*}{ H220-CONC-ORT-T11 } & Average & 121 & 236 & 320 & 387 \\
& Maximum & 561 & 777 & 890 & 954 \\
\cline { 2 - 6 } & Minimum & 32 & 72 & 164 & 162 \\
\cline { 2 - 6 } H220-CONC-ORT-T15 & Average & 120 & 234 & 318 & 386 \\
\cline { 2 - 6 } & Maximum & 560 & 770 & 886 & 951 \\
\hline H220-CONC-PAR-T11 & Minimum & 35 & 82 & 134 & 181 \\
\hline H220-CONC-PAR-T15 & - & 89 & 217 & 327 & 416 \\
\hline
\end{tabular}

\subsection{Analyses focused on the temperature of the concrete between the steel profile flanges}

For the determination of the average temperature in the concrete, ABNT NBR 14323 [3] disregards an external layer $\left(b_{c, f i}\right)$, for each TRRF, the thickness of which is provided by the item B.3.2.4.1 of the referred rule, which uses the mass factor of the composite section for its determination. This procedure allows you to identify which region the normative code is calculating the temperature for. Therefore, this value will be used to calculate the temperatures in the numerical models to compare with the normative values.

Regarding the normative temperature, it is also determined in function of the mass factor of the composite section, as well as the TRRF. It is important to mention that average temperature values in the concrete were determined by linear interpolation, according to ABNT NBR 14323 [3] in its item B.3.2.4.2.

For the case of the composite column with heating on all sides, Table 7 presents the values of the concrete temperatures obtained by the normative method and by the numerical model. It was found that the normative temperatures adequately represented the average numerical temperatures, only up to $60 \mathrm{~min}$ of exposure. For TRRF equal to 90 and $120 \mathrm{~min}$, the standard presented lower values than the numerical ones with maximum differences above $20 \%$. 
Table 7. Comparison of the temperatures obtained in the numerical model with the normative values for the concrete between the flanges of the columns with heating on all sides.

\begin{tabular}{cccccc}
\hline & TRRF $(\mathbf{m i n})$ & $\mathbf{3 0}$ & $\mathbf{6 0}$ & $\mathbf{9 0}$ & $\mathbf{1 2 0}$ \\
\hline Normative & & 240 & 346 & 434 & 484 \\
\hline \multirow{3}{*}{ H220-CONC-ISO } & Average & 158 & 361 & 529 & 658 \\
& Maximum & 254 & 489 & 658 & 774 \\
\cline { 2 - 6 } & Minimum & 141 & 331 & 496 & 625 \\
\hline
\end{tabular}

Concerning the columns inserted into walls, Table 8 shows the comparative study. In general, the normative results were superior to the average and minimum numerical results, being considered, in this aspect, conservative. On the other hand, when comparing them with the maximum numerical values, there was a very considerable difference with the norm, presenting smaller values.

\subsection{Temperature analysis in the longitudinal reinforcement}

ABNT NBR 14323 [3] establishes in its item B.3.2.5 that to obtain the temperature of the longitudinal reinforcements it is necessary, first, to calculate the geometric mean $\left(\mathrm{u}_{\mathrm{sm}}\right)$ of the distances $\mathrm{u}_{1}$ and $\mathrm{u}_{2}$, which correspond to the value of the distances between the bars centroid to the external faces of the concrete. From this, through of this same item of the standard, the reduction factor $\left(k_{y s, \theta}\right)$ of the reinforcement yield resistance as a function of the TRRF is determined.

Table 8. Comparison of the temperatures obtained in the numerical model and the theoretical values for the concrete between the flanges of the columns inserted into walls.

\begin{tabular}{|c|c|c|c|c|c|}
\hline Columns & TRRF (min) & 30 & 60 & 90 & 120 \\
\hline Normativo & & 240 & 346 & 434 & 484 \\
\hline \multirow{3}{*}{ H220-CONC-ORT-T11 } & Average & 66 & 157 & 240 & 315 \\
\hline & Maximum & 681 & 891 & 593 & 685 \\
\hline & Minimum & 25 & 54 & 104 & 154 \\
\hline \multirow{3}{*}{ H220-CONC-ORT-T15 } & Average & 49 & 127 & 200 & 272 \\
\hline & Maximum & 646 & 860 & 692 & 777 \\
\hline & Minimum & 25 & 58 & 95 & 120 \\
\hline \multirow{3}{*}{ H220-CONC-PAR-T11 } & Average & 50 & 134 & 389 & 474 \\
\hline & Maximum & 763 & 904 & 677 & 776 \\
\hline & Minimum & 29 & 75 & 178 & 234 \\
\hline \multirow{3}{*}{ H220-CONC-PAR-T15 } & Average & 73 & 190 & 345 & 429 \\
\hline & Maximum & 758 & 903 & 579 & 678 \\
\hline & Minimum & 25 & 48 & 90 & 217 \\
\hline
\end{tabular}

With the reduction factor calculated, the temperature of the reinforcement is determined from Table 1 of item 5.1.1.2 of the standard, which considers for each value found of the reduction factor, a corresponding temperature for the longitudinal reinforcement of CA-50 class.

For the four-sided heating column, Table 9 , the temperature results in the numerical model were not well represented by the normative values. In all cases, the theoretical temperatures were lower than the numerical ones, and the smallest difference was above $20 \%(120 \mathrm{~min})$.

Table 9. Comparison of the temperatures obtained in the numerical model and the theoretical values for longitudinal reinforcement of the columns with heating on all faces.

\begin{tabular}{ccccc}
\hline TRRF(min) & $\mathbf{3 0}$ & $\mathbf{6 0}$ & $\mathbf{9 0}$ & $\mathbf{1 2 0}$ \\
\hline Normative & 212 & 411 & 567 & 676 \\
\hline H220-CONC-ISO & 360 & 603 & 757 & 859 \\
\hline
\end{tabular}


In the case of columns inserted into walls, as shown in Table 10, the values of the average numerical temperature for this region were lower in relation to the values obtained by the normative method. Regarding H220-CONC-ORT11 and H220-CONC-ORT-T15 columns, the biggest differences in relation to average temperatures were approximately $461^{\circ} \mathrm{C}$ and $350^{\circ} \mathrm{C}$ at 120 minutes of heating, respectively. In contrast, for the columns H220-CONC-PAR-11 and H220CONC-PAR-T15, this difference was less than $230^{\circ} \mathrm{C}$.

Table 10. Comparison of the temperatures obtained in the numerical model and the theoretical values for longitudinal reinforcement of the columns inserted into walls.

\begin{tabular}{|c|c|c|c|c|c|}
\hline Columns & TRRF (min) & 30 & 60 & 90 & 120 \\
\hline Normative & & 212 & 411 & 567 & 676 \\
\hline \multirow{3}{*}{ H220-CONC-ORT-T11 } & Average & 65 & 158 & 170 & 215 \\
\hline & Maximum & 96 & 231 & 339 & 430 \\
\hline & Minimum & 33 & 85 & 148 & 212 \\
\hline \multirow{3}{*}{ H220-CONC-ORT-T15 } & Average & 88 & 177 & 258 & 326 \\
\hline & Maximum & 153 & 305 & 420 & 509 \\
\hline & Minimum & 24 & 50 & 95 & 142 \\
\hline \multirow{3}{*}{ H220-CONC-PAR-T11 } & Average & 171 & 316 & 422 & 503 \\
\hline & Maximum & 302 & 527 & 670 & 773 \\
\hline & Minimum & 39 & 105 & 174 & 233 \\
\hline \multirow{3}{*}{ H220-CONC-PAR-T15 } & Average & 36 & 269 & 369 & 447 \\
\hline & Maximum & 248 & 443 & 579 & 678 \\
\hline & Minimum & 36 & 94 & 158 & 217 \\
\hline
\end{tabular}

\section{CONCLUSIONS}

This article presented numerical analyses carried out in a thermal context, using the ABAQUS computational package, considering eight steel and steel and concrete composite columns. Of those two were isolated steel columns and six were steel columns inserted into 11 and $15 \mathrm{~cm}$ thick walls, to evaluate the thermal field developed in the structural elements.

When comparing similar positions of steel columns and steel and concrete composite columns, it was possible to note a reduction in temperature in the latter elements as a consequence of the concrete properties (low thermal conductivity and high specific heat). In relation to the composite columns inserted into walls, results indicate that the thermal field started to be reduced by the contribution of both concrete and the compartmentalization element. Regarding the thermal gradients presented by the columns inserted into walls, it is perceived a greater value for the cases in which the columns present the web orthogonal to the wall surface.

In addition to assessing the influence of the compartmentalization element and concrete on the thermal field of the columns, a comparison was made between the temperature evolution of steel and steel and concrete composite columns with that obtained from the application of the simplified methods suggested by ABNT NBR 14323 [3] and Eurocode 3 and 4 Part 1-2 [4,5]. Regarding steel columns, the simplified method was able to reproduce the evolution of temperatures only for elements with uniform heating on the four faces. However, in the case of steel columns inserted into walls, the normative method proved to be quite in favor of safety when comparing it with the field of average and minimum temperatures of the numerical models.

When evaluating the specific method of the Brazilian standard ABNT NBR 14323 [3] for the case of composite columns, it was found that adjustments are necessary to define a sufficiently satisfactory method for both the isolated columns and those inserted into walls. The simplified method was developed for isolated composite columns. Even so, in these cases, the normative temperature of the concrete for TRRF values above $90 \mathrm{~min}$, as well as the reinforcement temperatures for any TRRF were found to be lower than those from the numerical models. Regarding the flange and the web of the steel profile, the standard was in favor of safety.

Finally, regarding the composite columns inserted into walls, although there is no mention in the current normative codes about the temperature calculation for this structural design, the existing method for isolated composite columns was applied. The results showed that in many cases, the standard was very conservative to the point of showing differences for numerical temperatures above $400{ }^{\circ} \mathrm{C}$. 


\section{REFERENCES}

[1] A. J. P. M. Correia and J. P. C. Rodrigues, "Fire resistance of partially encased steel columns with restrained thermal elongation," $J$. Construct. Steel Res., vol. 67, no. 4, pp. 593-601, Apr 2011. http://dx.doi.org/10.1016/j.jcsr.2010.12.002.

[2] Y. S. Simoes, "F. M. Rocha and J. Munaiar No., "Comparação numérica entre o comportamento termoestrutural de pilares de aço e mistos de aço e concreto parcialmente revestidos em situação de incêndio," Rev. IBRACON Estrut. Mater., vol. 11, no. 4, pp. 876901, Jul. 2018. http://dx.doi.org/10.1590/s1983-41952018000400012.

[3] Associação Brasileira de Normas Técnicas, Projeto de estruturas de aço e de estruturas mistas de aço e concreto de edificios em situação de incêndio, ABNT NBR 14323, 2013.

[4] European Committee for Standardization, Eurocode 3 - Design of Steel Structures. Part 1-2: General rules - Structural Fire Design, EN 1993-1-2, 2005.

[5] European Committee for Standardization, Eurocode 4 - Design of composite steel and concrete structures. Part 1-2: General rulesStructural Fire Design, EN 1994-1-2, 2005.

[6] A. J. P. M. Correia, J. P. C. Rodrigues and P. V. Real, "Thermal bowing on steel columns embedded on walls under fire conditions," Fire Saf. J., vol. 67, pp. 53-69, Jul. 2014, http://dx.doi.org/10.1016/j.firesaf.2014.05.001.

[7] F. M. Rocha "Pilares de aço e misto de aço e concreto inseridos em paredes em situação de incêndio," Thesis, Esc. Eng. São Carlos, Uni. São Paulo, São Carlos, Brasil, 2016.

[8] M. M. S. Dwaikat and V. K. R. Kodur, "A simplified approach for evaluating plastic axial and moment capacity curves for beamcolumns with non-uniform thermal gradients," Eng. Struct., vol. 32, no. 5, pp. 1423-1436, May 2010. http://dx.doi.org/10.1016/j.engstruct.2010.01.021.

[9] M. M. S. Dwaikat, "V. K. R. Kodur, S. E. Quiel and M. E. M. Garlock, "Experimental behavior of steel beam-columns subjected to fire-induced thermal gradients," J. Construct. Steel Res., vol. 67, no. 1, pp. 30-38, Jan. 2011., http://dx.doi.org/10.1016/j.jcsr.2010.07.007.

[10] A. Agarwal, "L. Choe and A. H. Varma, "Fire design of steel columns: Effects of thermal gradients," J. Construct. Steel Res., vol. 93, pp. 107-118, Feb. 2014., http://dx.doi.org/10.1016/j.jcsr.2013.10.023.

[11] G. M. Kamil, "Q. Q. Liang and M. N. S. Hadi, "Fiber element simulation of interaction behavior of local and global buckling in axially loaded rectangular concrete-filled steel tubular slender columns under fire exposure," Thin-walled Struct., vol. 145, pp. 1-15, Dec. 2019., http://dx.doi.org/10.1016/j.tws.2019.106403.

[12] P. B. Lourenço “Computational strategies for masonry structures,” Ph.D. dissertation, Delft Univ. Press, Delft Univ. Tech., Delft, 1996.

[13] International Organization for Standardization. Fire-resistance tests - Elements of building construct - Part 1: General requirements, ISO 834, 1999.

[14] European Committee for Standardization. Eurocode 1 - Actions on structures - Part 1-2: General actions - Actions on structures exposed to fire, EN 1991-1-2, 2002.

[15] J. F. Cadorin, “Compartment fire models for structural engineering," Thèse, Doctorat en Sciences Appkiquéés, Faculté de Sciences Applpiques, Uni. Liège, Belgium, 2003.

[16] Y. S. Simoes, F. M. Rocha and J. Munaiar No., “Análises numérica e paramétrica de pilares de aço isolados submetidos a elevadas temperaturas," Rev. Estrutura Aco, vol. 8, no. 1, pp. 60-79, Apr. 2019.

Author contributions: MLR: Conceptualization, data curation, methodology, writing; YSS: Conceptualization, data curation, methodology, writing; JMN: supervision, formal analysis; ALC: supervision, formal analysis.

Editors: Yury Andrés Villagrán Zaccardi, Guilherme Aris Parsekian. 